\title{
Pharmacological Treatment of Dementia: A Scoping Review of Systematic Reviews
}

\author{
Esther M.M. van de Glind ${ }^{a}$ b $\quad$ Wynanda A. van Enst ${ }^{b}$ \\ Barbara C. van Munster ${ }^{a, d}$ Marcel G.M. Olde Rikkert ${ }^{e} \quad$ Philip Scheltens $^{c}$ \\ Rob J.P.M. Scholten ${ }^{b}$ Lotty Hooft ${ }^{b}$ \\ a Section of Geriatrics, Department of Internal Medicine, Academic Medical Center, \\ ${ }^{b}$ Dutch Cochrane Centre, Academic Medical Center, University of Amsterdam, and \\ 'Alzheimer Center, VU University Medical Center, Amsterdam, dDepartment of Geriatric \\ Medicine, Gelre Hospitals, Apeldoorn, and e Department of Geriatrics, Radboud Alzheimer \\ Centre, Radboud University Medical Centre, Nijmegen, The Netherlands
}

\section{Key Words}

Systematic reviews - Evidence-based medicine - Dementia - Scoping review .

Pharmacological treatment · Alzheimer's disease - Vascular dementia · Lewy body disease ·

Parkinson dementia $\cdot$ Frontotemporal dementia

\begin{abstract}
Background: Until now, multiple reviews on the pharmacological treatment of dementia have been published. Methods: We performed a scoping review to summarize research findings and to identify gaps in the existing literature. We searched the literature and assessed the risk of bias of the included reviews. A team of clinical experts assessed the fields in which more research is necessary. Fifty-five reviews with a low risk of bias were included, most of them concerning the treatment of cognitive decline $(n=16)$ and behavioral symptoms $(n=10)$ in Alzheimer's disease (AD). For cognitive impairment, cholinesterase inhibitors $(n=13)$ and memantine $(n=7)$ were described most frequently. Little information was found about the treatment of depression in dementia. Conclusions: For many current treatments, there is sufficient evidence. New research should focus on the symptomatic treatment of the earliest and most salient complaints in $A D$ as well as on disease-modifying interventions acting at the level of the amyloid cascade.

This scoping review was performed for the Healthcare Insurance Board (www.cvz.nl), but the organization was not involved in the research process and the writing of the manuscript. 
van de Glind et al:: Pharmacological Treatment of Dementia: A Scoping Review of Systematic Reviews

\section{Introduction}

Dementia is a group of chronic diseases characterized by a constant decline in the function of multiple cognitive domains comprising memory impairment, behavioral problems, loss of initiative, loss of independence in daily activities and loss of participation in social activities. It can be due to the direct physiological effects of a general medical condition, to the persisting effects of a substance or to multiple etiologies [1]. These problems with cognitive function decrease the quality of life of dementia patients and their caregivers, and put pressure on family relationships and friendships [2]. It is a highly prevalent condition, with Alzheimer's disease (AD) being the most common cause. The prevalence of dementia increases from $0.9 \%$ in 65- to 69-year-olds to over $30 \%$ in patients aged 85 years and older [3]. According to the World Health Organization, the total number of people with dementia worldwide in 2010 is estimated at 35.6 million and is projected to nearly double every 20 years. Between 2000 and 2008 , deaths due to $\mathrm{AD}$ have risen $66 \%$ in the United States [2]. The population-attributable risk of AD regarding mortality over 5 years in people aged 65 years is estimated to be between 5 and 15\% [4]. The disease causes a high financial burden on health care services: the current global costs involved in dementia are estimated to be more than USD 600 billion per year [2].

One of the most important issues is that patients with dementia cannot be cured, but the process of cognitive deterioration can merely be delayed. In many countries, cholinesterase inhibitors and memantine are registered for the treatment of cognitive impairment in AD. Furthermore, a wide range of medication is used for the behavioral and psychological symptoms in dementia. In the past few years, a large amount of research has been published at a rapid rate concerning different aspects of the disease, ranging from diagnostic tests and treatment options to the organization of care.

To develop or practice best care, clinicians and guideline makers often use systematic reviews since these summarize available evidence in a systematic way with enhanced precision. A large number of systematic reviews on diagnostic and medical interventions for dementia are available. However, these separate systematic reviews do not directly provide overarching insights into the extent and range of established evidence in a specific field.

This scoping review was carried out for the Healthcare Insurance Board, a consulting agency that advises the Dutch government on implementing the Dutch statutory health insurance [5]. The aim was to get an overview of currently registered pharmacological therapies for dementia about which systematic reviews are available. An evidence-based approach offers the most objective way to determine high quality and safety standards in clinical practice. It facilitates the process of transferring results of clinical research to practice and it has the potential to reduce healthcare costs, for example by disinvestment of ineffective practices.

In this scoping review, we provide an overview of available systematic reviews on the pharmacological treatment of the most prevalent forms of dementia and identify the fields in which more research is necessary.

\section{Methods}

\section{Scoping Review Framework}

A scoping study is a relatively new methodology to systematically review an extensive body of literature that addresses a broad research question [6]. While a systematic review focuses on retrieving an answer to a well-defined question, a scoping review 'maps' the relevant literature in a complete field of interest and describes only the main findings. According to Arksey and O'Malley [7], the aim of a scoping review is not to analyze or draw conclusions. Consequently, the present work should be seen as a first step to provide an overview of the existing literature and to identify the fields in which more research might be necessary in the future. 
van de Glind et al.: Pharmacological Treatment of Dementia: A Scoping Review of Systematic Reviews

Table 1. Quality assessment of the included systematic reviews

\begin{tabular}{ll}
\hline Assessment & Prerequisite \\
\hline Low risk of bias ++ & All 5 items were adequately addressed/well covered \\
Low risk of bias + & $\begin{array}{l}\text { 3 items were adequately addressed/well covered } \\
\text { High risk of bias - }\end{array}$ \\
$\begin{array}{l}\text { Both the literature search and the quality assessment were hardly/not addressed } \\
\geq 3 \text { items were hardly/not addressed }\end{array}$ \\
\hline
\end{tabular}

'Not applicable' was scored as neutral.

Our study comprised the following steps: identifying the clinical question, searching for relevant reviews, appraising the quality of the reviews [with the Scottish Institute of Guidelines Network (SIGN) checklist], categorizing the topics of the included systematic reviews and consulting experts in the research fields $[6,7]$.

\section{Identification of Reviews}

We performed a systematic search for systematic reviews published in MEDLINE, EMBASE, CINAHL and PsychINFO in September 2011 and in the Cochrane Database of Systematic Reviews (CDSR) in May 2012. The search was based on a search strategy developed by Kroes et al. [8]. Terms for dementia were combined with names of dementia medications, and the search terms were retrieved with the program PubReMiner, a textmining program that gives a frequency analysis of used terms in titles and abstracts of the identified reviews [9]. We used a sensitive systematic review filter of the SIGN [10] to further specify the search. The search strategy is available from the authors.

\section{Selection of Reviews}

We included systematic reviews of randomized controlled trials (RCTs), clinical controlled trials or observational studies that investigated a pharmacological intervention for dementia. Eligible reviews had to include patients with dementia [AD, vascular dementia, Lewy body disease (DLB) or Parkinson dementia, frontotemporal dementia and a category named 'unspecified dementia' that contained dementia in general or mixed forms]. In addition, the reviews had to be published or updated between 2008 and December 2011, written in English, French, German or Dutch and the full text article had to be accessible. For updated Cochrane reviews, the original publication dates were used. Reviews were excluded when (a) they assessed patients with mild cognitive impairment or dementia in Down syndrome or AIDS; (b) the medication was not registered by the European Medicines Agency (EMA) [11] or the Food and Drug Association (FDA) [12] (e.g. experimental medications or alternative drugs), and (c) the intervention only aimed at the outcomes of caregivers. One reviewer screened the titles and abstracts of the references for eligibility, two reviewers independently selected the full text articles, and a third reviewer was consulted when the first two reviewers were uncertain about the inclusion of a review article.

\section{Risk of Bias Assessment}

The methodology checklist for systematic reviews and meta-analyses of the SIGN (five items) was used to assess the risk of bias of the included reviews [10]. The items of this checklist were adapted to our topic and summarized in a total estimation of the risk of bias (table 1). A detailed description of the quality assessment is available from the authors. Two researchers independently performed the quality assessment, and when necessary, disagreements were resolved through discussion with a third reviewer.

\section{Data Extraction}

A standardized data extraction form was used to systematically extract the data from reviews with a low risk of bias (++ or + according to the SIGN checklist; table 1).

To provide an overview of the subjects included in the systematic reviews, we developed a matrix (table 2a-d). Each part of table 2 describes one type of dementia [unspecified dementia (including mixed types), AD, Parkinson dementia and DLB as well as vascular dementia]. Then, we categorized the medications into mechanisms of action or drug classes and made categories of symptoms that were addressed in the 
van de Glind et al.: Pharmacological Treatment of Dementia: A Scoping Review o Systematic Reviews

Table 2. Studies with a low risk of bias, listed according to the different dementia types

a Available evidence with a low risk of bias: unspecified dementia

\begin{tabular}{|c|c|c|c|c|c|c|c|c|c|c|}
\hline $\begin{array}{l}\text { Medical treat- } \\
\text { ment (number } \\
\text { of reviews) }\end{array}$ & $\begin{array}{l}\text { Behavioral } \\
\text { symptoms }^{1}\end{array}$ & $\begin{array}{l}\text { Neuro- } \\
\text { psychiatric } \\
\text { symptoms }^{2}\end{array}$ & $\begin{array}{l}\text { Adverse } \\
\text { events }\end{array}$ & $\begin{array}{l}\text { Cognitive } \\
\text { decline }\end{array}$ & $\begin{array}{l}\text { Depres- } \\
\text { sion }\end{array}$ & $\begin{array}{l}\text { Sleep } \\
\text { disorders }\end{array}$ & $\begin{array}{l}\text { ADL/ } \\
\text { institution- } \\
\text { alization }\end{array}$ & $\begin{array}{l}\text { Morbi- } \\
\text { dity }\end{array}$ & $\begin{array}{l}\text { Quality of } \\
\text { life }\end{array}$ & Other \\
\hline $\begin{array}{l}\text { Analgesic agents } \\
(n=1)\end{array}$ & $\begin{array}{l}\text { Husebo [44] } \\
\text { Kim [45] }\end{array}$ & & & & & & & & & \\
\hline $\begin{array}{l}\text { Anticonvulsive } \\
\text { agents }(n=2)\end{array}$ & $\begin{array}{l}\text { Konovalov } \\
{[54]}\end{array}$ & $\begin{array}{l}\text { Konovalov } \\
{[54]}\end{array}$ & $\begin{array}{l}\text { Lonergan } \\
{[49]}\end{array}$ & & & $\begin{array}{l}\text { Konovalov } \\
{[54]}\end{array}$ & & & & \\
\hline $\begin{array}{l}\text { Antidepressive } \\
\text { agents }(n=5)\end{array}$ & $\begin{array}{l}\text { Henry [56] } \\
\text { Seitz [55] } \\
\text { Martinón [48] }\end{array}$ & $\begin{array}{l}\text { Seitz } \\
{[55]}\end{array}$ & $\begin{array}{l}\text { Seitz [55] } \\
\text { Bains [42] } \\
\text { Sterke [51] }\end{array}$ & Bains [42] & Bains [42] & Henry [56] & & & & \\
\hline $\begin{array}{l}\text { Antihypertensive } \\
\text { agents }(n=2)\end{array}$ & & & Birks [35] & $\begin{array}{l}\text { Birks [35] } \\
\text { Shah [14] }\end{array}$ & & & Birks [35] & & & \\
\hline $\begin{array}{l}\text { Antipsychotic } \\
\text { agents }(n=4)\end{array}$ & $\begin{array}{l}\text { Gentile [53] } \\
\text { Lonergan } \\
{[50]}\end{array}$ & $\begin{array}{l}\text { Gentile } \\
{[53]}\end{array}$ & $\begin{array}{l}\text { Sterke [51] } \\
\text { Mittal [52] } \\
\text { Gentile [53] }\end{array}$ & & & & & & & \\
\hline $\begin{array}{l}\text { Benzodiazepines } \\
(n=1)\end{array}$ & & & Sterke [51] & & & & & & & \\
\hline $\begin{array}{l}\text { Fatty acids/ } \\
\text { nutritional } \\
\text { supplements }(n=1)\end{array}$ & & & & & & & Hanson [65] & $\begin{array}{l}\text { Hanson } \\
{[65]}\end{array}$ & $\begin{array}{l}\text { Hanson } \\
{[65]}\end{array}$ & $\begin{array}{l}\text { Hanson [65]: } \\
\text { weight; mortality; } \\
\text { pressure ulcer } \\
\text { healing }\end{array}$ \\
\hline $\begin{array}{l}\text { Ginkgo biloba } \\
(\mathrm{n}=1)\end{array}$ & $\begin{array}{l}\text { Birks [31] } \\
\text { Weinmann } \\
{[13]}\end{array}$ & & $\begin{array}{l}\text { Birks [31] } \\
\text { Weinmann } \\
{[13]}\end{array}$ & $\begin{array}{l}\text { Birks [31] } \\
\text { Weinmann } \\
{[13]}\end{array}$ & & & $\begin{array}{l}\text { Birks [31] } \\
\text { Weinmann } \\
{[13]}\end{array}$ & & $\begin{array}{l}\text { Birks [31] } \\
\text { Weinmann } \\
{[13]}\end{array}$ & \\
\hline $\begin{array}{l}\text { Hormone therapy } \\
(\mathrm{n}=2)\end{array}$ & Guay [66] & & $\begin{array}{l}\text { Bolea- } \\
\text { Alamanac } \\
{[46]}\end{array}$ & & $\begin{array}{l}\text { Hogervorst } \\
{[67]}\end{array}$ & & & & & \\
\hline Memantine $(n=1)$ & $\begin{array}{l}\text { McShane } \\
{[43]}\end{array}$ & $\begin{array}{l}\text { McShane } \\
{[43]}\end{array}$ & $\begin{array}{l}\text { McShane } \\
{[43]}\end{array}$ & $\begin{array}{l}\text { McShane } \\
{[43]}\end{array}$ & & & $\begin{array}{l}\text { McShane } \\
{[43]}\end{array}$ & & & \\
\hline Piracetam $(\mathrm{n}=1)$ & & & & Flicker [36] & & & & & & \\
\hline Melatonin $(n=2)$ & $\begin{array}{l}\text { de Jonghe } \\
\text { [47] } \\
\text { Jansen [37] }\end{array}$ & & & Jansen [37] & $\begin{array}{l}\text { Jansen } \\
\text { [37] }\end{array}$ & $\begin{array}{l}\text { de Jonghe } \\
\text { [47] } \\
\text { Jansen [37] }\end{array}$ & & & & \\
\hline Statins $(n=1)$ & $\begin{array}{l}\text { McGuinness } \\
{[41]}\end{array}$ & & $\begin{array}{l}\text { McGuinness } \\
{[41]}\end{array}$ & $\begin{array}{l}\text { McGuinness } \\
\text { [41] }\end{array}$ & & & $\begin{array}{l}\text { McGuinness } \\
{[41]}\end{array}$ & & $\begin{array}{l}\text { McGuinness } \\
\text { [41] }\end{array}$ & \\
\hline $\begin{array}{l}\text { Vitamins/minerals } \\
(\mathrm{n}=3)\end{array}$ & & & & $\begin{array}{l}\text { Malouf } \\
{[38-40]}\end{array}$ & & & & & & \\
\hline
\end{tabular}

b Available evidence with a low risk of bias: AD

\begin{tabular}{|c|c|c|c|c|c|c|c|c|c|c|}
\hline $\begin{array}{l}\text { Medical treat- } \\
\text { ment (number } \\
\text { of reviews) }\end{array}$ & $\begin{array}{l}\text { Behavioral } \\
\text { symptoms }^{1}\end{array}$ & $\begin{array}{l}\text { Neuro- } \\
\text { psychiatric } \\
\text { symptoms }^{2}\end{array}$ & $\begin{array}{l}\text { Adverse } \\
\text { events }\end{array}$ & $\begin{array}{l}\text { Cognitive } \\
\text { decline }\end{array}$ & $\begin{array}{l}\text { Depres- } \\
\text { sion }\end{array}$ & $\begin{array}{l}\text { Sleep } \\
\text { disorders }\end{array}$ & $\begin{array}{l}\text { ADL/ } \\
\text { institution- } \\
\text { alization }\end{array}$ & $\begin{array}{l}\text { Mor- } \\
\text { bidity }\end{array}$ & $\begin{array}{l}\text { Quality } \\
\text { of life }\end{array}$ & Other \\
\hline $\begin{array}{l}\text { Analgesic agents } \\
(n=1)\end{array}$ & Kim [45] & $\operatorname{Kim}[45]$ & & & & & & & & \\
\hline $\begin{array}{l}\text { Antidepressive } \\
\text { agents }(n=1)\end{array}$ & & & & & & $\begin{array}{l}\text { Salami } \\
{[29]}\end{array}$ & & & & \\
\hline $\begin{array}{l}\text { Antihypertensive } \\
\text { agents }(n=1)\end{array}$ & & & & Shah [14] & & & & & & \\
\hline $\begin{array}{l}\text { Antipsychotic } \\
\text { agents }(n=1)\end{array}$ & & & & & & $\begin{array}{l}\text { Salami } \\
{[29]}\end{array}$ & & & & \\
\hline
\end{tabular}


Dementia

Cognitive Disorders

\begin{tabular}{l|l}
\hline \multicolumn{2}{l}{ Dement Geriatr Cogn Disord 2013;36:211-228 } \\
\hline DOI: $\underline{10.1159 / 000353892}$ & $\begin{array}{l}\text { @ } 2013 \text { S. Karger AG, Basel } \\
\text { www.karger.com/dem }\end{array}$ \\
\hline
\end{tabular}

van de Glind et al.: Pharmacological Treatment of Dementia: A Scoping Review of Systematic Reviews

Table 2 (continued)

\begin{tabular}{|c|c|c|c|c|c|c|c|c|c|}
\hline $\begin{array}{l}\text { Aspirin/NSAIDs } \\
(\mathrm{n}=4)\end{array}$ & $\begin{array}{l}\text { Jaturapatporn } \\
{[24]}\end{array}$ & & $\begin{array}{l}\text { Tabet } \\
{[25,26]} \\
\text { Thoonsen } \\
\text { [27] } \\
\text { Jaturapa- } \\
\text { tporn [24] }\end{array}$ & $\begin{array}{l}\text { Tabet } \\
{[25,26]} \\
\text { Thoonsen } \\
\text { [27] } \\
\text { Jaturapa- } \\
\text { tporn [24] }\end{array}$ & $\begin{array}{l}\text { Jaturapa- } \\
\text { tporn } \\
{[24]}\end{array}$ & & $\begin{array}{l}\text { Jatura- } \\
\text { patporn } \\
{[24]}\end{array}$ & & $\begin{array}{l}\text { Jaturapatporn } \\
{[24] \text { : }} \\
\text { death; clinical } \\
\text { global impression } \\
\text { of change; } \\
\text { caregiver burden }\end{array}$ \\
\hline $\begin{array}{l}\text { Cholinesterase } \\
\text { inhibitors }(n=7)\end{array}$ & $\begin{array}{l}\text { Birks [16-18] } \\
\text { Rodda [68] }\end{array}$ & & $\begin{array}{l}\text { Birks } \\
{[16-18]} \\
\text { Lockhart } \\
{[22]}\end{array}$ & $\begin{array}{l}\text { Birks [16-18] } \\
\text { Cappell [21] }\end{array}$ & & $\begin{array}{l}\text { Salami } \\
\text { [29] }\end{array}$ & $\begin{array}{l}\text { Birks } \\
{[16-18]}\end{array}$ & & $\begin{array}{l}\text { Birks [17]: } \\
\text { cost-effectiveness } \\
\text { Rodda [68]: } \\
\text { apathy }\end{array}$ \\
\hline $\begin{array}{l}\text { Ginkgo biloba } \\
(\mathrm{n}=2)\end{array}$ & $\begin{array}{l}\text { Weinmann } \\
\text { [13] }\end{array}$ & & $\begin{array}{l}\text { Weinmann } \\
{[13]} \\
\text { Man [32] }\end{array}$ & $\begin{array}{l}\text { Weinmann } \\
\text { [13] }\end{array}$ & $\begin{array}{l}\text { Weinmann } \\
{[13]}\end{array}$ & & $\begin{array}{l}\text { Weinmann } \\
\text { [13] }\end{array}$ & $\begin{array}{l}\text { Weinmann } \\
\text { [13] }\end{array}$ & \\
\hline $\begin{array}{l}\text { Hormone therapy } \\
(\mathrm{n}=1)\end{array}$ & & & & & & $\begin{array}{l}\text { Salami } \\
\text { [29] }\end{array}$ & & & \\
\hline $\begin{array}{l}\text { Memantine } \\
(n=5)\end{array}$ & $\begin{array}{l}\text { Grossberg } \\
{[69]} \\
\text { Maidment } \\
{[15]}\end{array}$ & $\begin{array}{l}\text { Grossberg } \\
\text { [69] }\end{array}$ & & $\begin{array}{l}\text { Cappell [21] } \\
\text { McKeage [23] } \\
\text { Schneider } \\
{[70]}\end{array}$ & & & $\begin{array}{l}\text { McKeage } \\
{[23]} \\
\text { Schneider } \\
{[70]}\end{array}$ & & $\begin{array}{l}\text { Cappell [21], } \\
\text { McKeage [23]: } \\
\text { cost-effectiveness }\end{array}$ \\
\hline $\begin{array}{l}\text { Selegiline } \\
(n=1)\end{array}$ & & & Birks [71] & Birks [71] & & & & Birks [71] & \\
\hline Nicotine $(\mathrm{n}=1)$ & & & & $\begin{array}{l}\text { López- } \\
\text { Arrieta } \\
\text { [28] }\end{array}$ & & & & & \\
\hline $\begin{array}{l}\text { Vitamins/minerals } \\
(\mathrm{n}=2)\end{array}$ & $\begin{array}{l}\text { El-Kareem- } \\
\text { Nasr [72] }\end{array}$ & & & $\begin{array}{l}\text { El-Kareem- } \\
\text { Nasr [72] } \\
\text { Rodríguez } \\
{[30]}\end{array}$ & & & $\begin{array}{l}\text { El-Kareem- } \\
\text { Nasr [72] }\end{array}$ & & \\
\hline Steroidal $(n=1)$ & $\begin{array}{l}\text { Jaturapatporn } \\
{[24]}\end{array}$ & & $\begin{array}{l}\text { Jatura- } \\
\text { patporn } \\
{[24]}\end{array}$ & $\begin{array}{l}\text { Jatura- } \\
\text { patporn } \\
{[24]}\end{array}$ & $\begin{array}{l}\text { Jatura- } \\
\text { patporn } \\
{[24]}\end{array}$ & & $\begin{array}{l}\text { Jatura- } \\
\text { patporn } \\
{[24]}\end{array}$ & & $\begin{array}{l}\text { Jaturapatporn } \\
\text { [24]: death; } \\
\text { clinical global } \\
\text { impression of } \\
\text { change; caregiver } \\
\text { burden }\end{array}$ \\
\hline
\end{tabular}

c Available evidence with a low risk of bias: Parkinson dementia and DLB

\begin{tabular}{|c|c|c|c|c|c|c|c|c|c|c|}
\hline $\begin{array}{l}\text { Medical treat- } \\
\text { ment (number } \\
\text { of reviews) }\end{array}$ & $\begin{array}{l}\text { Behavioral } \\
\text { symptoms }^{1}\end{array}$ & $\begin{array}{l}\text { Neuro- } \\
\text { psychiatric } \\
\text { symptoms }^{2}\end{array}$ & $\begin{array}{l}\text { Adverse } \\
\text { events }\end{array}$ & $\begin{array}{l}\text { Cognitive } \\
\text { decline }\end{array}$ & $\begin{array}{l}\text { Depres- } \\
\text { sion }\end{array}$ & $\begin{array}{l}\text { Sleep } \\
\text { disorders }\end{array}$ & $\begin{array}{l}\text { ADL/ } \\
\text { institution- } \\
\text { alization }\end{array}$ & $\begin{array}{l}\text { Morbi- } \\
\text { dity }\end{array}$ & $\begin{array}{l}\text { Quality of } \\
\text { life }\end{array}$ & Other \\
\hline $\begin{array}{l}\text { Cholinesterase } \\
\text { inhibitors }(n=3)\end{array}$ & & $\begin{array}{l}\text { Rolinski } \\
{[20]}\end{array}$ & $\begin{array}{l}\text { Rolinski } \\
{[20]} \\
\text { Maidment } \\
\text { [19] } \\
\text { Wild [73] }\end{array}$ & $\begin{array}{l}\text { Rolinski } \\
{[20]} \\
\text { Maidment } \\
{[19]}\end{array}$ & & & $\begin{array}{l}\text { Rolinski } \\
{[20]} \\
\text { Maidment } \\
{[19]}\end{array}$ & & $\begin{array}{l}\text { Rolinski } \\
{[20]}\end{array}$ & $\begin{array}{l}\text { Rolinski [20]: } \\
\text { global } \\
\text { assessment; } \\
\text { effect on carers; } \\
\text { effect on } \\
\text { Parkinson } \\
\text { features; death; } \\
\text { health economics }\end{array}$ \\
\hline
\end{tabular}

d Available evidence with a low risk of bias: vascular dementia

\begin{tabular}{|c|c|c|c|c|c|c|c|c|c|c|}
\hline $\begin{array}{l}\text { Medical treat- } \\
\text { ment (number } \\
\text { of reviews) }\end{array}$ & $\begin{array}{l}\text { Behavioral } \\
\text { symptoms }^{1}\end{array}$ & $\begin{array}{l}\text { Neuro- } \\
\text { psychiatric } \\
\text { symptoms }^{2}\end{array}$ & $\begin{array}{l}\text { Adverse } \\
\text { events }\end{array}$ & $\begin{array}{l}\text { Cognitive } \\
\text { decline }\end{array}$ & $\begin{array}{l}\text { Depres- } \\
\text { sion }\end{array}$ & $\begin{array}{l}\text { Sleep } \\
\text { disorders }\end{array}$ & $\begin{array}{l}\text { ADL/ } \\
\text { institution- } \\
\text { alization }\end{array}$ & $\begin{array}{l}\text { Morbi- } \\
\text { dity }\end{array}$ & $\begin{array}{l}\text { Quality } \\
\text { of life }\end{array}$ & Other \\
\hline $\begin{array}{l}\text { Antidepressive } \\
\text { agents }(n=1)\end{array}$ & & & & Levine [74] & & & & & & \\
\hline $\begin{array}{l}\text { Antihypertensive } \\
\text { agents }(n=2)\end{array}$ & Levine [74] & & & Shah [14] & & & & & & \\
\hline $\begin{array}{l}\text { Aspirin/NSAIDs } \\
(\mathrm{n}=1)\end{array}$ & & & & Levine [74] & & & & & & $\begin{array}{l}\text { Levine [74]: } \\
\text { prevention }\end{array}$ \\
\hline
\end{tabular}


Table 2 (continued)

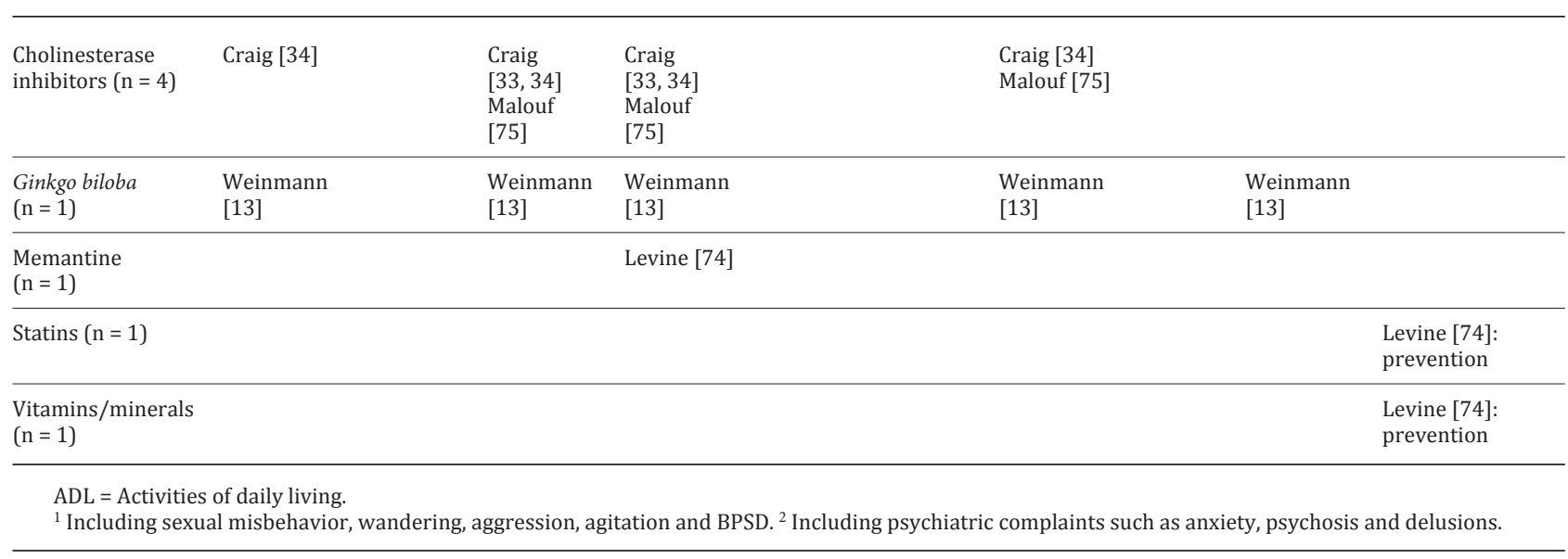

reviews. We put all these data in the matrix; by doing this per intervention it became clear whether a systematic review was available for the outcome. The categories were approved by experts in the different fields. For the high-quality reviews, we quoted a sentence from the abstract that summarizes the conclusions of the articles (table 3).

\section{Consultation of Experts}

An expert panel was involved to comment on the findings (i.e. whether they were consistent or conflicting with current practice) and to indicate if they missed relevant topics. In addition, we asked the experts which relevant practical developments they expect for the near future and for which topics they would advise future research.

Based on project time lines and cost considerations, we recruited several experts from different medical fields and geographical regions in the Netherlands. Our expert panel, composed of a neurologist, a psychiatrist, a specialist for internal medicine, a geriatrician and a caregiver of a dementia patient, commented on the steps in several phases of the review process by personal communication, e.g., via e-mail contact. These expert-based comments were added to the overview of systematic reviews.

\section{Results}

The findings are presented as an overview of available systematic reviews and the fields in which more research is necessary. Some reviews are mentioned more than once because they cover more than one topic. More details of the reviews included in this scoping study can be obtained from the authors.

\section{Identification of Studies}

The search yielded 1,569 records. Based on title and abstract, we read the full texts of 119 articles. In the end, 62 articles, including 34 Cochrane reviews, fulfilled the predefined inclusion criteria (fig. 1). The most prevalent reason for excluding a review was that the reported intervention was not FDA or EMA registered. Out of the 62 reviews, 55 (90\%) reviews were assessed as having a low risk of bias. To describe the results, only the reviews with a low risk of bias were used. 
van de Glind et al.: Pharmacological Treatment of Dementia: A Scoping Review of Systematic Reviews

Table 3. Quotes from high-quality reviews summarizing the conclusions of the articles

a Overview of included studies: unspecified dementia $(n=29)$

\begin{tabular}{lll}
\hline Author & Medical treatment & Quote \\
\hline Bains [42] & Antidepressants & $\begin{array}{l}\text { 'Available evidence offers weak support to the contention that antidepressants are } \\
\text { effective for patients with depression and dementia. However, only four studies are } \\
\text { included in the meta-analysis relating to efficacy, and sample sizes are small. Moreover, } \\
\text { only two included studies investigated the properties of the more commonly used SSRIs } \\
\text { and no studies investigated the properties of newer classes of antidepressants (e.g. } \\
\text { selective noradrenergic reuptake inhibitors). This review draws attention to the paucity } \\
\text { of research and evidence in this area.' }\end{array}$
\end{tabular}

Birks [35] Nimodipine 'Nimodipine can be of some benefit in the treatment of patients with features of dementia due to unclassified disease or to Alzheimer's disease, cerebrovascular disease, or mixed Alzheimer's and cerebrovascular disease. It appears to be well tolerated with few side effects. Data were not available from several trials, a total of more than 500 patients. A meta-analysis of individual patient data from all trials is desirable. Dementia is a chronic disorder and the short-term benefits of nimodipine demonstrated in the trials reviewed do not justify its use as a long-term anti-dementia drug. New research must focus on longer term outcomes.'

Birks [31] Ginkgo biloba Ginkgo biloba appears to be safe in use with no excess side effects compared with placebo. Many of the early trials used unsatisfactory methods were small, and publication bias cannot be excluded. The evidence that Ginkgo biloba has predictable and clinically significant benefit for people with dementia or cognitive impairment is inconsistent and unreliable.'

\begin{tabular}{|c|c|c|}
\hline $\begin{array}{l}\text { Bolea-Alamanac } \\
{[46]}\end{array}$ & Cyproterone & $\begin{array}{l}\text { 'Despite there being evidence to support our observations of a useful role for cyproterone } \\
\text { in aggressivity in dementia, further studies are needed to establish the efficacy and safety } \\
\text { of this therapeutic option.' }\end{array}$ \\
\hline de Jonghe [47] & Melatonin & $\begin{array}{l}\text { 'Sundowning/agitated behaviour improves with melatonin treatment in patients with } \\
\text { dementia.' }\end{array}$ \\
\hline Flicker [36] & Piracetam & $\begin{array}{l}\text { 'Published evidence does not support the use of piracetam in the treatment of people with } \\
\text { dementia or cognitive impairment. Although effects were found on global impression of } \\
\text { change, no benefit was shown by any of the more specific measures of cognitive function.' }\end{array}$ \\
\hline Gentile [53] & SGAs & $\begin{array}{l}\text { 'Because of their undemonstrated effectiveness, SGAs should be avoided in patients with } \\
\text { dementia complicated by psychotic and/or behavioural symptoms. Hence, further } \\
\text { researches are urgently needed to identify useful pharmacological strategies that can be } \\
\text { used to improve the clinical condition of such patients and to reduce burden to caregivers } \\
\text { when behavioural interventions are ineffective.' }\end{array}$ \\
\hline Guay [66] & $\begin{array}{l}\text { Treatments for } \\
\text { inappropriate sexual } \\
\text { behavior }\end{array}$ & $\begin{array}{l}\text { 'In general, unless the patient is engaging in or threatening dangerous acts involving } \\
\text { physical contact, serotoninergics (first choice, SSRls; second choice, TCAs) are first-line } \\
\text { agents (for abnormal sexual behavior) followed by antiandrogens (cyproterone acetate or } \\
\text { medroxyprogesterone acetate) as second-line agents. LHRH agonists (first choice) and } \\
\text { estrogens (second choice) are considered third-line agents. Combination therapy is } \\
\text { reasonable if the patient fails to respond to monotherapy.' }\end{array}$ \\
\hline Hanson [65] & $\begin{array}{l}\text { Oral feeding, feeding } \\
\text { supplements }\end{array}$ & $\begin{array}{l}\text { 'High-calorie supplements are an evidence-based option to promote weight gain for } \\
\text { people with dementia and feeding problems. Assisted feeding, appetite stimulants, and } \\
\text { modified foods may also improve weight, and treatments can be used individually or in } \\
\text { combination. Based on current evidence, specialized oral feeding interventions are } \\
\text { unlikely to change how people with dementia function or how long they live.' }\end{array}$ \\
\hline Henry [56] & Antidepressants & $\begin{array}{l}\text { 'This review indicates that antidepressants can be effective in the treatment of BPSD and } \\
\text { are generally well tolerated in elderly demented patients.' }\end{array}$ \\
\hline $\begin{array}{l}\text { Hogervorst } \\
{[67]}\end{array}$ & $\begin{array}{l}\text { Hormone } \\
\text { replacement } \\
\text { therapy }\end{array}$ & $\begin{array}{l}\text { 'Currently, hormone replacement therapy (HRT) or estrogen replacement therapy (ERT) } \\
\text { for cognitive improvement or maintenance is not indicated for women with Alzheimer } \\
\text { Dementia.' }\end{array}$ \\
\hline
\end{tabular}


van de Glind et al.: Pharmacological Treatment of Dementia: A Scoping Review o

Table 3 (continued)

\begin{tabular}{lll}
\hline Author & Medical treatment & Quote \\
\hline Husebo [44] & Pain treatment & $\begin{array}{l}\text { 'There is a profound dearth of rigorous studies of the effect of pain treatment in patients } \\
\text { with dementia and agitation. The available studies do not support the hypothesis that } \\
\text { pain management reduces agitation in nursing-home patients with dementia. } \\
\end{array}$ \\
& Randomized, controlled parallel-group studies are needed.'
\end{tabular}

Jansen [37] Melatonin

'The analyses did not support the use of melatonin for treatment of cognitive impairment associated with dementia. Meta-analysis of psychopathologic behavior scale scores suggested that melatonin may be effective in treating these dementia-related disturbances.'

\begin{tabular}{lll}
\hline $\begin{array}{l}\text { Konovalov } \\
\text { [54] }\end{array}$ & $\begin{array}{l}\text { Anticonvulsant } \\
\text { mood stabilizers }\end{array}$ & $\begin{array}{l}\text { 'Although clearly beneficial in some patients, anticonvulsant mood stabilizers cannot be } \\
\text { recommended for routine use in the treatment of BPSD at the present time.' }\end{array}$ \\
\hline $\begin{array}{l}\text { Lonergan } \\
\text { [50] }\end{array}$ & Haloperidol & $\begin{array}{l}\text { 'No evidence has been found of any significant general improvement in manifestations of } \\
\text { agitation, other than aggression, among demented patients treated with haloperidol, } \\
\text { compared with controls.' }\end{array}$ \\
\hline
\end{tabular}

\begin{tabular}{lll}
\hline $\begin{array}{l}\text { Lonergan } \\
\text { [49] }\end{array}$ & Valproate & $\begin{array}{l}\text { 'Valproate preparations are ineffective in treating agitation among demented patients, } \\
\text { and that valproate therapy is associated with an unacceptable rate of adverse effects.' }\end{array}$ \\
\hline $\begin{array}{l}\text { Maidment } \\
\text { [15] }\end{array}$ & $\begin{array}{l}\text { 'Memantine decreases NPI scores and may have a role in managing BPSD. However, there } \\
\text { are a number of limitations with the current data; the effect size was relatively small, and } \\
\text { whether memantine produces significant clinical benefit is not clear.' }\end{array}$
\end{tabular}

Malouf [39] Vitamin B12 'Vitamin B12 is essential for maintaining normal function of the nervous system, but the relationship between vitamin B12 and cognitive function is not fully understood. From the three studies involving people with dementia or cognitive impairment and low blood levels of vitamin B12 eligible for inclusion in this review there was no statistically significant effect of vitamin B12 supplementation on cognition. The variety of measurement scales used to assess outcomes and uncertainty about diagnostic criteria for vitamin B12 deficiency create difficulties in pooling the results of trials.'

Malouf [38] Vitamin B6

'This review found no evidence for short-term benefit from vitamin B6 in improving mood (depression, fatigue and tension symptoms) or cognitive functions. For the older people included in one of the two trials included in the review, oral vitamin B6 supplements improved biochemical indices of vitamin B6 status, but potential effects on blood homocysteine levels were not assessed in either study. This review found evidence that there is scope for increasing some biochemical indices of vitamin B6 status among older people. More randomized controlled trials are needed to explore possible benefits from vitamin B6 supplementation for healthy older people and for those with cognitive impairment or dementia.'

\begin{tabular}{lll}
\hline Malouf [40] & $\begin{array}{l}\text { Folic acid with or } \\
\text { without vitamin B12 }\end{array}$ & $\begin{array}{l}\text { 'The small number of studies which have been done provide no consistent evidence either } \\
\text { way that folic acid, with or without vitamin B12, has a beneficial effect on cognitive } \\
\text { function of unselected healthy or cognitively impaired older people.' }\end{array}$ \\
\hline $\begin{array}{l}\text { Martinón } \\
\text { [48] }\end{array}$ & $\begin{array}{l}\text { Trazodone } \\
\text { 'There is insufficient evidence to recommend the use of trazodone as a treatment for } \\
\text { behavioural and psychological manifestations of dementia. In order to assess } \\
\text { effectiveness and safety of trazodone, longer-term randomized controlled trials are } \\
\text { needed, involving larger samples of participants with a wider variety of types and } \\
\text { severities of dementia.' }\end{array}$ \\
\hline McGuinness & Statins & $\begin{array}{l}\text { 'There is insufficient evidence to recommend statins for the treatment of dementia. } \\
\text { Analysis from the studies available, including one large RCT, indicate statins have no } \\
\text { benefit on the outcome measures ADAS-Cog or MMSE. We need to await full results from } \\
\text { CLASP 2008 }{ }^{1} \text { before we can be certain. This Cochrane review will be updated as these } \\
\text { results become available.' }\end{array}$ \\
& 'Memantine has a small beneficial effect at six months in moderate to severe Alzheimer \\
& Dementia. In patients with mild to moderate dementia, the small beneficial effect on \\
McShane & Megnition was not clinically detectable in those with vascular dementia and was \\
[43] & &
\end{tabular}




\section{Dementia}

\begin{tabular}{l|l}
\hline \multicolumn{2}{l}{ Dement Geriatr Cogn Disord 2013;36:211-228 } \\
\hline DOI: $\underline{10.1159 / 000353892}$ & $\begin{array}{l}\text { @ 2013 S. Karger AG, Basel } \\
\text { www.karger.com/dem }\end{array}$ \\
\hline
\end{tabular}

van de Glind et al.: Pharmacological Treatment of Dementia: A Scoping Review of Systematic Reviews

Table 3 (continued)

\begin{tabular}{|c|c|c|}
\hline Author & Medical treatment & Quote \\
\hline Mittal [52] & Antipsychotics & $\begin{array}{l}\text { 'Although some psychotropic medications have shown modest efficacy in the treatment of } \\
\text { these behaviors, their use has generated controversy due to increasing recognition of the } \\
\text { side effects of these medications especially the antipsychotic medications (...). Available } \\
\text { evidence indicates that antipsychotic medications increase the risk of cerebrovascular } \\
\text { adverse events and death when used to treat elderly patients with Behavioral and } \\
\text { Psychological Symptoms of Dementia.' }\end{array}$ \\
\hline Seitz [55] & Antidepressants & $\begin{array}{l}\text { 'The SSRIs sertraline and citalopram were associated with a reduction in symptoms of } \\
\text { agitation when compared to placebo in two studies. Both SSRIs and trazodone appear to } \\
\text { be tolerated reasonably well when compared to placebo, typical antipsychotics and } \\
\text { atypical antipsychotics.' }\end{array}$ \\
\hline Shah [14] & Antihypertensives & $\begin{array}{l}\text { 'Antihypertensive medications - particularly ACE inhibitors and diuretics - may be } \\
\text { helpful in reducing the risk for and progression of dementia. Large randomized clinical } \\
\text { trials are warranted to further explore the relationship between antihypertensive drugs } \\
\text { and dementia.' }\end{array}$ \\
\hline Sterke [51] & $\begin{array}{l}\text { Psychoactive drugs, } \\
\text { antidepressants, } \\
\text { antianxiety drugs }\end{array}$ & $\begin{array}{l}\text { 'Research on the contribution of psychoactive drugs to fall risk in nursing home residents } \\
\text { with dementia is limited. The scarce evidence shows, however, that multiple drugs, } \\
\text { antidepressants and anti-anxiety drugs increase fall risk in nursing home populations } \\
\text { with residents with dementia.' }\end{array}$ \\
\hline $\begin{array}{l}\text { Weinmann } \\
{[13]}\end{array}$ & Ginkgo biloba & $\begin{array}{l}\text { 'Ginkgo biloba appears more effective than placebo. Effect sizes were moderate, while } \\
\text { clinical relevance is, similar to other dementia drugs, difficult to determine.' }\end{array}$ \\
\hline
\end{tabular}

b Overview of included studies: $\mathrm{AD}(\mathrm{n}=22)$

\begin{tabular}{|c|c|c|}
\hline Author & Medical treatment & Quote \\
\hline Birks [71] & Selegiline & $\begin{array}{l}\text { 'Despite its initial promise, i.e. the potential neuroprotective properties, and its role in the } \\
\text { treatment of Parkinson's disease, selegiline for Alzheimer's disease has proved } \\
\text { disappointing. Although there is no evidence of a significant adverse event profile, there is } \\
\text { also no evidence of a clinically meaningful benefit for people with Alzheimer's disease. } \\
\text { There would seem to be no justification, therefore, to use it for Alzheimer's disease, nor } \\
\text { for any further studies of its efficacy in Alzheimer's disease.' }\end{array}$ \\
\hline Birks [16] & $\begin{array}{l}\text { Cholinesterase } \\
\text { inhibitors }\end{array}$ & $\begin{array}{l}\text { 'The three cholinesterase inhibitors are efficacious for mild to moderate Alzheimer's } \\
\text { disease. Despite the slight variations in the mode of action of the three cholinesterase } \\
\text { inhibitors there is no evidence of any differences between them with respect to efficacy. } \\
\text { The evidence from one large trial shows fewer adverse events associated with donepezil } \\
\text { compared with rivastigmine.' }\end{array}$ \\
\hline Birks [17] & Donepezil & $\begin{array}{l}\text { 'There is some evidence that use of donepezil is neither more nor less expensive } \\
\text { compared with placebo when assessing total health care resource costs. Benefits on the } \\
10 \mathrm{mg} / \text { day dose were marginally larger than on the } 5 \mathrm{mg} / \text { day dose. Taking into } \\
\text { consideration the better tolerability of the } 5 \mathrm{mg} / \text { day donepezil compared with the } 10 \mathrm{mg} / \\
\text { day dose, together with the lower cost, the lower dose may be the better option. The } \\
\text { debate on whether donepezil is effective continues despite the evidence of efficacy from } \\
\text { the clinical studies because the treatment effects are small and are not always apparent in } \\
\text { practice, and because of the cost of the drug.' }\end{array}$ \\
\hline Birks [18] & Rivastigmine & $\begin{array}{l}\text { 'Rivastigmine appears to be beneficial for people with mild to moderate Alzheimer's } \\
\text { disease. In comparisons with placebo, improvements were seen in the rate of decline of } \\
\text { cognitive function, activities of daily living, and severity of dementia with daily doses of } 6 \\
\text { to } 12 \mathrm{mg} \text {. Adverse events were consistent with the cholinergic actions of the drug. A } \\
\text { transdermal patch has been tested in one trial, and there is evidence that the lower dose } \\
\text { smaller patch is associated with fewer side effects than the capsules or the higher dose } \\
\text { larger patch and has comparable efficacy to both. This review has not examined economic } \\
\text { data.' }\end{array}$ \\
\hline
\end{tabular}


van de Glind et al.: Pharmacological Treatment of Dementia: A Scoping Review of Systematic Reviews

Table 3 (continued)

\begin{tabular}{|c|c|c|}
\hline Author & Medical treatment & Quote \\
\hline Cappell [21] & $\begin{array}{l}\text { Donepezil, } \\
\text { memantine, } \\
\text { galantamine, } \\
\text { rivastigmine }\end{array}$ & $\begin{array}{l}\text { 'When viewed from the social perspective, pharmacotherapy (donepezil, memantine, } \\
\text { galantamine, rivastigmine) has the potential to reduce the economic burden of the illness, } \\
\text { even in later stages of this disease, though more rigorous pharmacoeconomic studies are } \\
\text { still needed.' }\end{array}$ \\
\hline $\begin{array}{l}\text { El-Kareem-Nasr } \\
{[72]}\end{array}$ & Vitamin E & $\begin{array}{l}\text { 'This review found no evidence for efficacy of vitamin E in the treatment of AD. Taken } \\
\text { together with other evidence that vitamin E, especially in the large doses used in the } \\
\text { included studies, may be associated with potentially significant side effects and even an } \\
\text { increased rate of all-cause mortality, we conclude that vitamin E should not be used in the } \\
\text { treatment of AD.' }\end{array}$ \\
\hline Grossberg [69] & Memantine & $\begin{array}{l}\text { 'Overall, patients who received memantine performed better on behavioral measures } \\
\text { than those treated with placebo.' }\end{array}$ \\
\hline $\begin{array}{l}\text { Jaturapatporn } \\
\text { [24] }\end{array}$ & NSAIDs & $\begin{array}{l}\text { 'Based on the studies carried out so far, the efficacy of aspirin, steroid and NSAIDs } \\
\text { (traditional NSAIDs and COX-2 inhibitors) is not proven. Therefore, these drugs cannot be } \\
\text { recommended for the treatment of AD.' }\end{array}$ \\
\hline $\operatorname{Kim}[45]$ & Gabapentin & $\begin{array}{l}\text { 'The dearth of available data limits support for the off-label use of gabapentin for the } \\
\text { treatment of BPSD. Furthermore, controlled studies should be conducted before } \\
\text { gabapentin can be clinically indicated for the successful treatment of BPSD.' }\end{array}$ \\
\hline Lockhart [22] & $\begin{array}{l}\text { Donepezil, } \\
\text { rivastigmine, } \\
\text { galantamine }\end{array}$ & $\begin{array}{l}\text { 'Subjects with mild to moderate AD treated in routine clinical practice with donepezil } \\
\text { were more adherent to pharmacotherapy, and had a lower risk of gastrointestinal adverse } \\
\text { effects compared with rivastigmine or galantamine. This finding accords with results } \\
\text { reported in the randomised clinical trial literature.' }\end{array}$ \\
\hline $\begin{array}{l}\text { López-Arrieta } \\
\text { [28] }\end{array}$ & Nicotine & $\begin{array}{l}\text { 'This review is not able to provide any evidence that nicotine is or is not a useful } \\
\text { treatment for Alzheimer's disease.' }\end{array}$ \\
\hline Man [32] & Ginkgo biloba & $\begin{array}{l}\text { 'Among various herbal medicines (HMs), the safety and tolerability of Ginkgo biloba was } \\
\text { best established. Further multi-center trials with large sample size, high methodological } \\
\text { qualities and standardized HM ingredients are necessary for clinical recommendations on } \\
\text { the use of HM in treating AD.' }\end{array}$ \\
\hline $\begin{array}{l}\text { Maidment } \\
\text { [15] }\end{array}$ & Memantine & $\begin{array}{l}\text { 'Memantine decreases NPI scores and may have a role in managing BPSD. However, there } \\
\text { are a number of limitations with the current data; the effect size was relatively small, and } \\
\text { whether memantine produces significant clinical benefit is not clear.' }\end{array}$ \\
\hline $\begin{array}{l}\text { McKeage } \\
{[23]}\end{array}$ & Memantine & $\begin{array}{l}\text { 'In the management of patients with moderate to severe Alzheimer's disease, memantine } \\
\text { provides an effective treatment option. To date, clinical trial support is greater for } \\
\text { memantine use in combination with an AChE inhibitor, while more data are needed to } \\
\text { confirm its efficacy as monotherapy.' }\end{array}$ \\
\hline Rodda [68] & $\begin{array}{l}\text { Cholinesterase } \\
\text { inhibitors }\end{array}$ & $\begin{array}{l}\text { 'The evidence is limited, in part due to methodological considerations. In the absence of } \\
\text { alternative safe and effective management options, the use of cholinesterase inhibitors is } \\
\text { an appropriate pharmacological strategy for the management of BPSD in Alzheimer's } \\
\text { disease.' }\end{array}$ \\
\hline $\begin{array}{l}\text { Rodríguez } \\
\text { [30] }\end{array}$ & Thiamine & $\begin{array}{l}\text { 'It is not possible to draw any conclusions from this review. The number of people } \\
\text { included in the studies is less than } 50 \text { and the reported results are inadequate.' }\end{array}$ \\
\hline Salami [29] & $\begin{array}{l}\text { Treatments } \\
\text { targeting sleep } \\
\text { disturbance }\end{array}$ & $\begin{array}{l}\text { 'Most current treatments targeting sleep disturbance in Alzheimer's dementia are } \\
\text { ineffective. There is a need for further investigation of interventions for treating sleep } \\
\text { disturbance in Alzheimer's dementia.' }\end{array}$ \\
\hline $\begin{array}{l}\text { Schneider } \\
\text { [70] }\end{array}$ & Memantine & $\begin{array}{l}\text { 'Despite its frequent off-label use, evidence is lacking for a benefit of memantine in mild } \\
\mathrm{AD} \text {, and there is meager evidence for its efficacy in moderate AD.' }\end{array}$ \\
\hline Shah [14] & $\begin{array}{l}\text { Antihypertensive } \\
\text { medications }\end{array}$ & $\begin{array}{l}\text { 'Antihypertensive medications - particularly ACE inhibitors and diuretics - may be } \\
\text { helpful in reducing the risk for and progression of dementia. Large randomized clinical } \\
\text { trials are warranted to further explore the relationship between antihypertensive drugs } \\
\text { and dementia.' }\end{array}$ \\
\hline Tabet [25] & Indomethacin & $\begin{array}{l}\text { 'On the basis of this one trial and subsequent analysis of data as reported by the authors, } \\
\text { indomethacin cannot be recommended for the treatment of mild to moderate severity } \\
\text { Alzheimer's disease. At doses of 100-150 mg daily, serious side effects will limit its use.' }\end{array}$ \\
\hline
\end{tabular}




\section{Dementia}

\begin{tabular}{l|l}
\hline \multicolumn{2}{l}{ Dement Geriatr Cogn Disord 2013;36:211-228 } \\
\hline DOI: $\underline{10.1159 / 000353892}$ & $\begin{array}{l}\text { @ 2013 S. Karger AG, Basel } \\
\text { www.karger.com/dem }\end{array}$ \\
\hline
\end{tabular}

van de Glind et al.: Pharmacological Treatment of Dementia: A Scoping Review of Systematic Reviews

Table 3 (continued)

\begin{tabular}{|c|c|c|}
\hline Author & Medical treatment & Quote \\
\hline Tabet [26] & Ibuprofen & $\begin{array}{l}\text { 'No evidence yet exists from randomized double-blind and placebo-controlled trials on } \\
\text { whether ibuprofen is efficacious for patients diagnosed as having Alzheimer's disease. } \\
\text { Ibuprofen, like other NSAIDs, has an identifiable and in some instances a significant side- } \\
\text { effect profile which may include gastrointestinal bleeding. Therefore, it needs to be shown } \\
\text { that the benefits of such a treatment outweigh the risk of side effects before ibuprofen can } \\
\text { be recommended for people with Alzheimer's disease.' }\end{array}$ \\
\hline $\begin{array}{l}\text { Thoonsen } \\
\text { [27] }\end{array}$ & Aspirin & $\begin{array}{l}\text { 'Although the number of cases in both trials is small, our findings suggest that aspirin use } \\
\text { in AD might pose an increased risk of intracerebral hemorrhages (ICH), whereas it has no } \\
\text { effect on cognition. If there is an unequivocal cardiovascular indication for aspirin, it } \\
\text { should not be withheld in AD patients.' }\end{array}$ \\
\hline $\begin{array}{l}\text { Weinmann } \\
\text { [13] }\end{array}$ & Ginkgo biloba & $\begin{array}{l}\text { 'Ginkgo biloba appears more effective than placebo. Effect sizes were moderate, while } \\
\text { clinical relevance is, similar to other dementia drugs, difficult to determine.' }\end{array}$ \\
\hline
\end{tabular}

c Overview of included studies: vascular dementia $(n=6)$

\begin{tabular}{|c|c|c|}
\hline Author & Medical treatment & Quote \\
\hline Craig [34] & Rivastigmine & $\begin{array}{l}\text { 'Although existing trial data indicated some benefit of rivastigmine in vascular cognitive } \\
\text { impairment (VCI), these were derived from studies which had small numbers of patients, } \\
\text { and which compared rivastigmine to treatments other than placebo or extrapolated } \\
\text { results post hoc from large studies involving patients with Alzheimer's disease and } \\
\text { vascular risk factors of unclear significance. They could not be included in this review. } \\
\text { Proper randomized placebo-controlled double-blind trials involving patients with VCI are } \\
\text { needed before any conclusions regarding the use of rivastigmine in VCI can be drawn.' }\end{array}$ \\
\hline Craig [33] & Galantamine & $\begin{array}{l}\text { 'The efficacy of galantamine has been tested in two RCTs for the treatment of vascular } \\
\text { dementia and for a mixed population of Alzheimer's disease patients with evidence of } \\
\text { cerebrovascular disease. The rationale behind its use is to correct the cholinergic deficit } \\
\text { seen in vascular dementia. This review found evidence of benefit in measures of cognition } \\
\text { including executive functioning in one study but no clear advantage over placebo in } \\
\text { another study when patients with pure vascular dementia were considered. Both studies } \\
\text { indicated higher rates of nausea and vomiting in actively treated participants.' }\end{array}$ \\
\hline
\end{tabular}

\begin{tabular}{ll}
\hline Levine [74] & Pharmacological 'This is a very broad overview article; no general conclusion can be made.' \\
& and \\
& nonpharmacological \\
& interventions for \\
& vascular dementia
\end{tabular}

Malouf [75] Donepezil 'Evidence from the available studies supports the benefit of donepezil in improving cognition function, clinical global impression and activities of daily living in patients with probable or possible mild to moderate vascular cognitive impairment after 6 months treatment. Extending studies for longer periods would be desirable to establish the efficacy of donepezil in patients with advanced stages of cognitive impairment. Moreover, there is an urgent need for establishing specific clinical diagnostic criteria and rating scales for vascular cognitive impairment.'

\begin{tabular}{lll}
\hline Shah [14] & $\begin{array}{l}\text { Antihypertensive } \\
\text { medications }\end{array}$ & $\begin{array}{l}\text { 'Antihypertensive medications - particularly ACE inhibitors and diuretics - may be } \\
\text { helpful in reducing the risk for and progression of dementia. Large randomized clinical } \\
\text { trials are warranted to further explore the relationship between antihypertensive drugs } \\
\text { and dementia.' }\end{array}$ \\
\hline $\begin{array}{l}\text { Weinmann } \\
{[13]}\end{array}$ & 'Ginkgo biloba & $\begin{array}{l}\text { 'Ginko biloba appears more effective than placebo. Effect sizes were moderate, while } \\
\text { clinical relevance is, similar to other dementia drugs, difficult to determine.' }\end{array}$ \\
\hline
\end{tabular}




\section{Dementia}

Cognitive Disorders

\begin{tabular}{l|l}
\hline \multicolumn{2}{l|}{ Dement Geriatr Cogn Disord 2013;36:211-228 } \\
\hline DOI: $\underline{10.1159 / 000353892}$ & $\begin{array}{l}\text { C 2013 S. Karger AG, Basel } \\
\text { www.karger.com/dem }\end{array}$ \\
\hline
\end{tabular}

van de Glind et al.: Pharmacological Treatment of Dementia: A Scoping Review of Systematic Reviews

Table 3 (continued)

d Overview of included studies: Parkinson dementia/DLB $(n=3)$

\begin{tabular}{lll}
\hline Author & Medical treatment & Quote \\
\hline Maidment [19] & $\begin{array}{l}\text { Cholinesterase } \\
\text { inhibitors }\end{array}$ & $\begin{array}{l}\text { 'Dementia is frequently associated with Parkinson's Disease. While a number of } \\
\text { neurotransmitters appear to be involved, loss of cholinergic functioning is particularly } \\
\text { associated with Parkinson's Disease Dementia (PDD) suggesting a potential utility for } \\
\text { cholinesterase inhibitors. Rivastigmine appears to moderately improve cognition and to a } \\
\text { lesser extent activities of daily living in patients with PDD. There was a clinically } \\
\text { meaningful benefit in 15\% of patients. Efficacy in other domains requires confirmation. } \\
\end{array}$ \\
& Tolerability in particular nausea, vomiting and tremor appear problematic.' \\
& $\begin{array}{l}\text { Cholinesterase } \\
\text { inhibitors }\end{array}$ & $\begin{array}{l}\text { The currently available evidence supports the use of cholinesterase inhibitors in patients } \\
\text { with PDD, with a positive impact on global assessment, cognitive function, behavioural } \\
\text { disturbance and activities of daily living rating scales. The effect in DLB remains unclear. } \\
\text { There is no current disaggregated evidence to support their use in CIND-PD.' }\end{array}$ \\
& Rivastigmine & $\begin{array}{l}\text { 'Patients with dementia with Lewy bodies who suffer from behavioural disturbance or } \\
\text { psychiatric problems may benefit from rivastigmine if they tolerate it, but the evidence is } \\
\text { weak. Further trials using rivastigmine are needed, as are trials of other cholinesterase } \\
\text { inhibitors in dementia with Lewy bodies.' }\end{array}$ \\
& &
\end{tabular}

${ }^{1}$ Sano M: Multi-center, randomized, double-blind, placebo-controlled trial of simvastatin to slow the progression of Alzheimer's disease. CLASP 2008. ICAD abstracts, 2008 (unpubl. data only).

\section{Risk of Bias Assessment}

Out of 62 reviews, 7 were considered as having a high risk of bias due to multiple flaws in the methodology (fig. 1). Fifty-five reviews scored a low risk of bias (++ or + according to the SIGN checklist). Of these, 34 received ++ and 21 received + . However, 13 of the + reviews lacked an assessment of the risk of bias of included studies, which means that the conclusions of these reviews are less reliable. The 55 low-risk-of-bias reviews can be found in table 2 .

\section{Description of Included Reviews with a Low Risk of Bias}

The 55 reviews with a low risk of bias mainly addressed the fields of Alzheimer $(n=22)$ and unspecified dementia (including mixed forms, $n=29$; table 2a, b). Surprisingly, treatment for Parkinson dementia/DLB and vascular dementia was assessed in only 3 and 6 reviews, respectively, and frontotemporal dementia in none (table 2c, d). The numbers increased to over 56 because some reviews addressed more than one type of dementia [13-15]. Most included reviews reported cognitive decline $(n=33)$, behavioral symptoms $(n=21)$ and adverse events $(n=26)$ as primary outcomes.

\section{Cognitive Decline}

$\mathrm{AD}$ and Parkinson Dementia/DLB

For cognitive decline in AD, 17 reviews were available. The reviews by Birks et al. [16-18] showed that cholinesterase inhibitors are efficacious for mild to moderate AD as well as for Parkinson dementia $[19,20]$, and they are cost-effective [17, 21]. With regard to the effects, the different drugs are comparable, but with respect to the side effects, donepezil might be the better choice [22].

Memantine proved to be effective for patients with moderate to severe AD, although not for other forms of dementia [23]. For many interventions such as aspirin, steroids and NSAIDs [24-27], nicotine [28], hormone replacement [29] and thiamine [30], the evidence for an 
Dementia

Cognitive Disorders

Fig. 1. Flow chart of the study selection process.

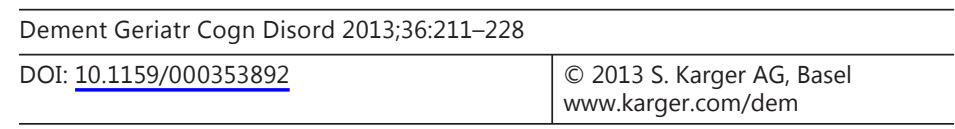

van de Glind et al.: Pharmacological Treatment of Dementia: A Scoping Review of Systematic Reviews

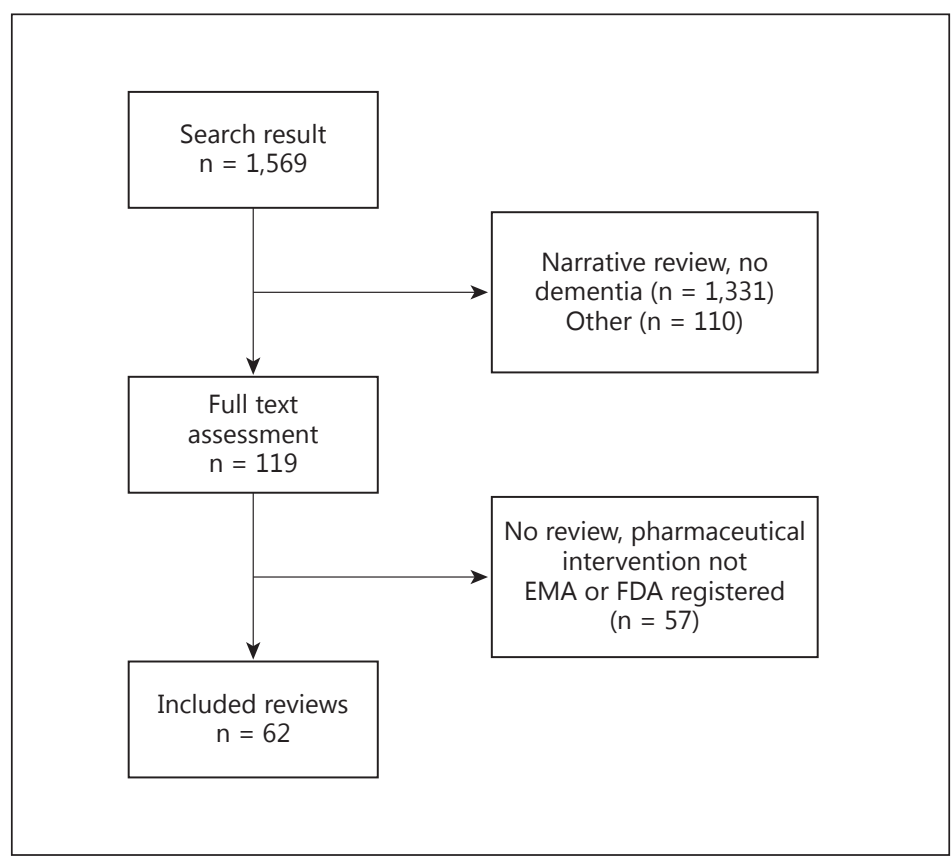

effect on cognitive decline is limited because of the lack of studies of high methodological quality and sufficient power. For Ginkgo biloba, the results are conflicting [13, 31], although it appears to be safe [32].

Vascular Dementia

For vascular dementia, the efficacy of galantamine has been tested in 2 studies; 1 found some evidence of benefit, whereas the other did not find clear advantage over the placebo [33]. For rivastigmine, no proper RCTs were available [34]. Therefore, cholinesterase inhibitors are not recommended for vascular dementia.

Unspecified Dementia

Nine reviews about cognitive decline in unspecified dementia were identified. For antihypertensives, there are indications that they are beneficial $[14,35]$. No evidence was found to support the use of piracetam [36], melatonin [37], vitamins [38-40], statins [41] and antidepressive agents [42].

\section{Behavioral Problems}

For this topic, no distinction between the different types of dementia was made. Twentyseven systematic reviews described interventions for behavioral problems such as agitation, aggression and behavioral and psychological symptoms of dementia (BPSD). According to McShane et al. [43], the use of memantine resulted in a consistent, small reduction in the incidence of agitation in demented patients. However, there was no available evidence addressing the question as to whether prevalent agitation can be treated with memantine. No studies or only studies of low methodological quality were available for pain medication [44, 45], and further studies are needed to establish the efficacy of cyproterone [46]. Melatonin has an effect in sundowning in demented patients [47], but trazodone [48], valproate [49] and haloperidol [50] have not shown any treatment effect for agitation among demented patients, whereas they have potential side effects [51-53]. 
van de Glind et al.: Pharmacological Treatment of Dementia: A Scoping Review of Systematic Reviews

\section{Neuropsychiatric Symptoms}

For this topic, no distinction between the different types of dementia was made. Eight reviews described neuropsychiatric symptoms such as hallucinations and delusions. No evidence was found for an effect of anticonvulsant mood stabilizers [54] and second-generation antipsychotics (SGAs) [53]. Moreover, SGAs increase the risk of falling in nursing home residents [51] and of cerebrovascular events [52]. Two reviews found that antidepressants can be effective in the treatment of BPSD [55,56], whereas Martinón et al. [48] found no effect of trazodone.

\section{Depression}

The number of reviews about depression in demented patients is small. Only 1 review showed weak support for antidepressants being effective in patients with depression and dementia (type not specified) [42].

\section{Patient-Centered Outcomes}

Activities of daily living, institutionalization and quality of life, although important from the patient's point of view, were only investigated as secondary outcomes. Table $2 \mathrm{a}-\mathrm{d}$ shows the reviews describing these outcomes.

\section{Expert Panel Survey Results}

The expert panel commented on the matrix (table $2 \mathrm{a}-\mathrm{d}$ ) and on the conclusions of the reviews (table 3). Furthermore, we asked the experts about promising interventions and implications for further research regarding the pharmacological treatment of dementia.

There are sufficient systematic reviews about the efficacy of cholinesterase inhibitors for cognitive impairment, mild to moderate stadia of AD and Parkinson dementia as these are most frequently used in current practice. In addition, various systematic reviews about the efficacy of memantine on cognition are available. For several other interventions such as NSAIDs, selegiline and hormone replacement, there is sufficient evidence to show that these are not effective.

Furthermore, the panel was asked about the topics they missed in the current literature on dementia. Little is known about the combination of cholinesterase inhibitor therapy with memantine, although recently a primary study has been published on this topic [57]. Neither is it known whether cholinesterase inhibitors are effective in combination with other drug types such as antihypertensive drugs. Furthermore, which cholinesterase inhibitor is preferable in the light of efficacy and side effects is still a topic of discussion, and little evidence is available regarding the continuation or discontinuation of these medications when the disease progresses [57]. Therefore, our expert team suggested that comparative effectiveness research should be performed instead of more placebo-controlled trials on these types of drug therapy.

It is striking that often drugs are prescribed for symptoms of demented patients, while aggregated evidence is lacking. For example, few reviews were published on the treatment of depression in dementia although depression is highly prevalent in dementia [58]. In addition, although epidemiological studies show that the number of patients with AD affected by delirium varies from 22 to $89 \%$ in the community and hospitalized populations [59], it is another striking example of a syndrome that is hardly studied in these patients. Likewise, few reviews address the ability of patients to live independently or to perform their activities of daily living without help, although these outcomes are likely to be meaningful for patients as well as their caregivers [60].

New research should focus on the symptomatic treatment of the earliest and most salient complaints in $\mathrm{AD}$ and on disease-modifying interventions acting at the level of the amyloid cascade. Promising nutritional interventions, immunotherapy acting at the level of the amyloid 
van de Glind et al.: Pharmacological Treatment of Dementia: A Scoping Review of Systematic Reviews

cascade, drugs that target tau, progranulin or TDP-43 are missing in this overview because these interventions are not yet registered for clinical use or are still in the development phase [61]. Consequently, systematic reviews on these topics have not been performed yet.

\section{Discussion}

We performed a scoping review that aimed to give an overview of the subjects and methodological quality of the currently available systematic reviews on the pharmacological treatment of the most prevalent forms of dementia. In addition, it identifies gaps in the existing literature and facilitates dissemination.

Our scoping review is the first systematic overview of recent systematic reviews regarding the pharmacological treatment of dementia. It shows that in the field of dementia, most research is designed to determine the effects of cholinesterase inhibitors, NMDA receptor antagonists and antipsychotics (table 2). Furthermore, our scoping review also shows that for many indications, no systematic review is available. Without aggregated evidence, it is difficult and time-consuming to provide evidence-based care to patients.

Several topics, such as the treatment of cognitive impairment in AD with cholinesterase inhibitors, have been thoroughly studied over the past few years. Starting up new projects on these topics thus is of little value. Head-to-head comparison trials to find out which intervention is best and when to discontinue such interventions are of greater interest for future research. Such research might better be performed as coordinated international prospective cohort studies in daily practice, as RCTs are expensive and time-consuming.

Many reviews about the treatment of behavioral problems have been published. From the available systematic reviews, it appeared that these kinds of symptoms are very difficult to treat with medication; moreover, currently used therapies such as antipsychotics have major side effects. Perhaps the management of these problems should rather be nonpharmacological, with interventions such as environmental modification, task simplification and appropriate activities [62, 63].

Our scoping review has a number of strengths. First, it provided a broad overview of both the recent systematic reviews available and the gaps in the literature concerning the pharmacological treatment of dementia. Second, we performed an extensive search in several databases; thereby, the chance of missing relevant publications was reduced. Furthermore, 2 independent assessors selected the reviews and determined the risk of bias, which reduced the chance of errors.

However, there are also some limitations worth noting. Although in general the quality of the systematic reviews in the field of pharmacological treatment options for dementia was high, the quality assessment of the primary studies was lacking in many cases. Whether the results of a systematic review can be relied on for clinical practice depends on two factors: its own risk of bias and the risk of bias of the included studies. It has been shown that even systematic reviews published in leading journals often have important methodological limitations potentially leading to biased results and different answers to the same question [64]. However, we have chosen to extract the data from these reviews as well because apart from such biased results, the reviews had been performed well and no alternative evidence with a smaller risk of bias was available.

For identifying the gaps in the literature, we relied on the expert panel. Although this expert panel consisted of prominent professionals from different branches involved in the treatment and care of demented patients, expert opinions are also dependent on personal interests and knowledge. Besides, all experts originated from the Netherlands. 
van de Glind et al.: Pharmacological Treatment of Dementia: A Scoping Review of Systematic Reviews

We have summarized the results in a narrative way and thereby relied on the reports of the authors. Investigating the extent of the drug effects and assessing their clinical relevance was beyond the scope of this overview. We checked for the presence of results regarding efficacy by looking at evidence from placebo-controlled trials and evidence regarding the difference in effect between various drugs. We also looked for evidence concerning side effects, but other factors such as pharmacoeconomics and implementation research are not described. Furthermore, because the aim of this scoping review was to give an overview of available reviews, new and unregistered medication is not reported. However, we have covered this topic in the expert opinion part.

\section{Conclusion}

This scoping review is a comprehensive overview of the currently available systematic reviews on the pharmacological treatment of dementia and thus a starting point for clinicians and guideline developers to find systematic reviews regarding various pharmacological treatments for dementia. It shows the gaps in the existing literature and indicates where future reviews and/or primary research might be necessary. When used as a starting point for guideline development, not only treatment effects are necessary. It is also important to know if the evidence identified is applicable to the patients to whom the guideline is directed (e.g. by looking at the results of comparative effectiveness research) and to consider other factors such as the patient perspective, available resources and local circumstances. Finally, this scoping review may guide the development of quality indicators, which are used more and more in implementing guidelines and assessing the value of treatment components.

\section{Acknowledgements}

We would like to thank Miranda Langendam, Pauline Heus and Roy Elbers from the Dutch Cochrane Centre for their contribution to the design and methods of this study. We would also like to thank René Spijker for his help with the development of the search strategy, and Prof. Dr. Raymond Koopmans for his clinical input as a member of the expert panel.

\section{Disclosure Statement}

None of the authors has personal, financial or potential conflicts of interest.

\section{References}

1 DSM-IV-TR: Diagnostic and Statistical Manual of Mental Disorders, ed 4 rev. Arlington, American Psychiatric Association, 2000.

2 World Health Organization: Dementia: A Public Health Priority, 2012.

- 3 Breteler MM, Ott A, Hofman A: The new epidemic: frequency of dementia in the Rotterdam Study. Haemostasis 1998;28:117-123.

4 Alzheimer's Association: 2012 Alzheimer's disease facts and figures. Alzheimers Dement 2012;8:131-168.

5 Healthcare Insurance Board, 2013.

- 6 Levac D, Colquhoun H, O’Brien KK: Scoping studies: advancing the methodology. Implement Sci 2010;5:69.

- 7 Arksey H, O’Malley L: Scoping studies: towards a methodological framework. Int J Soc Res Methodol 2005;8: 19-32.

8 Kroes M, Garcia-Stewart S, Allen F, Eyssen M, Paulus D: Dementia: which non-pharmacological interventions? KCE Reports 160C.Brussels, Belgian Health Care Knowledge Centre, 2011.

9 http://bioinfo.amc.uva.nl/human-genetics/pubreminer/. 
van de Glind et al.: Pharmacological Treatment of Dementia: A Scoping Review of Systematic Reviews

10 The Scottish Intercollegiate Guidelines Network (SIGN): Methodology Checklist 1:Systematic Reviews and Meta-Analyses. http://www.sign.ac.uk/methodology/checklists.html (accessed June 2012).

11 http://www.emea.europa.eu/ema/index.jsp?curl=pages/home/Home_Page.jsp\&mid= (accessed June 2012).

12 http://www.fda.gov/Drugs (accessed June 2012).

13 Weinmann S, Roll S, Schwarzbach C, Vauth C, Willich SN: Effects of Ginkgo biloba in dementia: systematic review and meta-analysis. BMC Geriatr 2010;10:14.

14 Shah K, Qureshi SU, Johnson M, Parikh N, Schulz PE, Kunik ME: Does use of antihypertensive drugs affect the incidence or progression of dementia? A systematic review. Am J Geriatr Pharmacother 2009; 7:250-261.

15 Maidment ID, Fox CG, Boustani M, Rodriguez J, Brown RC, Katona CL: Efficacy of memantine on behavioral and psychological symptoms related to dementia: a systematic meta-analysis. Ann Pharmacother 2008;42:32-38.

16 Birks J, Harvey RJ: Cholinesterase inhibitors for Alzheimer's disease. Cochrane Database Syst Rev 2006;CD005593.

17 Birks J, Harvey RJ: Donepezil for dementia due to Alzheimer's disease. Cochrane Database Syst Rev 2006;CD001190.

18 Birks J, Grimley EJ, Iakovidou V, Tsolaki M: Rivastigmine for Alzheimer's disease. Cochrane Database Syst Rev 2009;CD001191.

19 Maidment I, Fox C, Boustani M: Cholinesterase inhibitors for Parkinson's disease dementia. Cochrane Database Syst Rev 2006;CD004747.

20 Rolinski M, Fox C, Maidment I, McShane R: Cholinesterase inhibitors for dementia with Lewy bodies, Parkinson's disease dementia and cognitive impairment in Parkinson's disease. Cochrane Database Syst Rev 2012;CD006504.

21 Cappell J, Herrmann N, Cornish S, Lanctôt KL: The pharmacoeconomics of cognitive enhancers in moderate to severe Alzheimer's disease. CNS Drugs 2010;24:909-927.

22 Lockhart IA, Mitchell SA, Kelly S: Safety and tolerability of donepezil, rivastigmine and galantamine for patients with Alzheimer's disease: systematic review of the 'real-world' evidence. Dement Geriatr Cogn Disord 2009; 28:389-403.

23 McKeage K: Memantine: a review of its use in moderate to severe Alzheimer's disease. CNS Drugs 2009;23: 881-897.

24 Jaturapatporn D, Isaac MG, McCleery J, Tabet N: Aspirin, steroidal and non-steroidal anti-inflammatory drugs for the treatment of Alzheimer's disease. Cochrane Database Syst Rev 2012;CD006378.

25 Tabet N, Feldman H: Indomethacin for Alzheimer's disease. Cochrane Database Syst Rev 2002;CD003673.

26 Tabet N, Feldman H: Ibuprofen for Alzheimer's disease. Cochrane Database Syst Rev 2003;CD004031.

-27 Thoonsen H, Richard E, Bentham P, Gray R, van GN, De Haan RJ, van Gool WA, Nederkoorn PJ: Aspirin in Alzheimer's disease: increased risk of intracerebral hemorrhage: cause for concern? Stroke 2010;41:26902692.

28 López-Arrieta JM, Rodríguez JL, Sanz F: Nicotine for Alzheimer's disease. Cochrane Database Syst Rev 2001;CD001749.

29 Salami O, Lyketsos C, Rao V: Treatment of sleep disturbance in Alzheimer's dementia. Int J Geriatr Psychiatry 2011;26:771-782.

30 Rodríguez JL, Qizilbash N, López-Arrieta JM: Thiamine for Alzheimer's disease. Cochrane Database Syst Rev 2001;CD001498.

31 Birks J, Evans JG: Ginkgo biloba for cognitive impairment and dementia. Cochrane Database Syst Rev 2009;CD003120.

-32 Man SC, Durairajan SSK, Kum WF, Lu JH, Huang JD, Cheng CF, Chung V, Xu M, Li M: Systematic review on the efficacy and safety of herbal medicines for Alzheimer's disease. J Alzheimers Dis 2008;14:209-223.

33 Craig D, Birks J: Galantamine for vascular cognitive impairment. Cochrane Database Syst Rev 2006;CD004746.

34 Craig D, Birks J: Rivastigmine for vascular cognitive impairment. Cochrane Database Syst Rev 2005;CD004744.

35 Birks J, López-Arrieta JM: Nimodipine for primary degenerative, mixed and vascular dementia. Cochrane Database Syst Rev 2002;CD000147.

36 Flicker L, Grimley EJ: Piracetam for dementia or cognitive impairment. Cochrane Database Syst Rev 2004;CD001011.

37 Jansen SL, Forbes D, Duncan V, Morgan DG, Malouf R: Melatonin for the treatment of dementia. Cochrane Database Syst Rev 2006;CD003802.

38 Malouf R, Grimley EJ: Vitamin B6 for cognition. Cochrane Database Syst Rev 2003;CD004393.

39 Malouf R, Areosa SA: Vitamin B12 for cognition. Cochrane Database Syst Rev 2003;CD004394.

40 Malouf R, Grimley EJ: Folic acid with or without vitamin B12 for the prevention and treatment of healthy elderly and demented people. Cochrane Database Syst Rev 2008;CD004514.

41 McGuinness B, O'Hare J, Craig D, Bullock R, Malouf R, Passmore P: Statins for the treatment of dementia. Cochrane Database Syst Rev 2010;CD007514.

42 Bains J, Birks JS, Dening TR: The efficacy of antidepressants in the treatment of depression in dementia. Cochrane Database Syst Rev 2002;CD003944.

43 McShane R, Areosa SA, Minakaran N: Memantine for dementia. Cochrane Database Syst Rev 2006;CD003154.

44 Husebo BS, Ballard C, Aarsland D: Pain treatment of agitation in patients with dementia: a systematic review. Int J Geriatr Psychiatry 2011;26:1012-1018.

45 Kim Y, Wilkins KM, Tampi RR: Use of gabapentin in the treatment of behavioural and psychological symptoms of dementia: a review of the evidence. Drugs Aging 2008;25:187-196. 
van de Glind et al.: Pharmacological Treatment of Dementia: A Scoping Review of Systematic Reviews

46 Bolea-Alamanac BM, Davies SJC, Christmas DM, Baxter H, Cullum S, Nutt DJ: Cyproterone to treat aggressivity in dementia: a clinical case and systematic review. J Psychopharmacol 2011;25:141-145.

47 de Jonghe A, Korevaar JC, van Munster BC, de Rooij SE: Effectiveness of melatonin treatment on circadian rhythm disturbances in dementia. Are there implications for delirium? A systematic review. Int J Geriatr Psychiatry 2010;25:1201-1208.

48 Martinón TG, Fioravanti M, Grimley EJ: Trazodone for agitation in dementia. Cochrane Database Syst Rev 2004;CD004990.

49 Lonergan E, Luxenberg J: Valproate preparations for agitation in dementia. Cochrane Database Syst Rev 2009;CD003945.

50 Lonergan E, Luxenberg J, Colford JM, Birks J: Haloperidol for agitation in dementia. Cochrane Database Syst Rev 2002;CD002852.

51 Sterke CS, Verhagen AP, van Beeck EF, van der Cammen TJ: The influence of drug use on fall incidents among nursing home residents: a systematic review. Int Psychogeriatr 2008;20:890-910.

$\checkmark 52$ Mittal V, Kurup L, Williamson D, Muralee S, Tampi RR: Review: risk of cerebrovascular adverse events and death in elderly patients with dementia when treated with antipsychotic medications: a literature review of evidence. Am J Alzheimers Dis Other Demen 2011;26:10-28.

53 Gentile S: Second-generation antipsychotics in dementia: beyond safety concerns. A clinical, systematic review of efficacy data from randomised controlled trials. Psychopharmacology 2010;212:119-129.

54 Konovalov S, Muralee S, Tampi RR: Anticonvulsants for the treatment of behavioral and psychological symptoms of dementia: a literature review. Int Psychogeriatr 2008;20:293-308.

55 Seitz DP, Adunuri N, Gill SS, Gruneir A, Herrmann N, Rochon P: Antidepressants for agitation and psychosis in dementia. Cochrane Database Syst Rev 2011;CD008191.

56 Henry G, Williamson D, Tampi R: Efficacy and tolerability of antidepressants in the treatment of behavioral and psychological symptoms of dementia, a literature review of evidence. Am J Alzheimers Dis Other Demen 2011;26:169-183.

57 Howard R, McShane R, Lindesay J, Ritchie C, Baldwin A, Barber R, Burns A, Dening T, Findlay D, Holmes C, Hughes A, Jacoby R, Jones R, Jones R, McKeith I, Macharouthu A, O’Brien J, Passmore P, Sheehan B, Juszczak E, Katona C, Hills R, Knapp M, Ballard C, Brown R, Banerjee S, Onions C, Griffin M, Adams J, Gray R, Johnson T, Bentham P, Phillips P: Donepezil and memantine for moderate-to-severe Alzheimer's disease. N Engl J Med 2012;366:893-903.

58 Dal FG, Palermo MT, Donohue JE, Karagiozis H, Zonderman AB, Kawas CH: Depressive symptoms, sex, and risk for Alzheimer's disease. Ann Neurol 2005;57:381-387.

-59 Fick DM, Agostini JV, Inouye SK: Delirium superimposed on dementia: a systematic review. J Am Geriatr Soc 2002;50:1723-1732.

60 Reuben DB, Tinetti ME: Goal-oriented patient care - an alternative health outcomes paradigm. N Engl J Med 2012;366:777-779.

61 Ballard C, Gauthier S, Corbett A, Brayne C, Aarsland D, Jones E: Alzheimer's disease. Lancet 2011;377:10191031.

62 California Workgroup on Guidelines for Alzheimer's Disease Management: Guideline for Alzheimer's Disease Management. Chicago, Alzheimer's Association, 2008.

63 Scottish Intercollegiate Guidelines Network: Management of Patients with Dementia. Edinburgh, 2013, pp 13-20.

64 Gerber S, Tallon D, Trelle S, Schneider M, Juni P, Egger M: Bibliographic study showed improving methodology of meta-analyses published in leading journals 1993-2002. J Clin Epidemiol 2007;60:773-780.

65 Hanson LC, Ersek M, Gilliam R, Carey TS: Oral feeding options for people with dementia: a systematic review. J Am Geriatr Soc 2011;59:463-472.

66 Guay DR: Inappropriate sexual behaviors in cognitively impaired older individuals. Am J Geriatr Pharmacother 2008;6:269-288.

67 Hogervorst E, Yaffe K, Richards M, Huppert FAH: Hormone replacement therapy to maintain cognitive function in women with dementia. Cochrane Database Syst Rev 2009;CD003799.

68 Rodda J, Morgan S, Walker Z: Are cholinesterase inhibitors effective in the management of the behavioral and psychological symptoms of dementia in Alzheimer's disease? A systematic review of randomized, placebocontrolled trials of donepezil, rivastigmine and galantamine. Int Psychogeriatr 2009;21:813-824.

69 Grossberg GT, Pejovic V, Miller ML, Graham SM: Memantine therapy of behavioral symptoms in communitydwelling patients with moderate to severe Alzheimer's disease. Dement Geriatr Cogn Disord 2009;27:164172.

70 Schneider LS, Dagerman KS, Higgins JPT, McShane R: Lack of evidence for the efficacy of memantine in mild Alzheimer disease. Arch Neurol 2011;68:991-998.

71 Birks J, Flicker L: Selegiline for Alzheimer's disease. Cochrane Database Syst Rev 2003;CD000442.

72 El-Kareem-Nasr IMG, Quinn R, Tabet N: Vitamin E for Alzheimer's disease and mild cognitive impairment. Cochrane Database Syst Rev 2008;CD002854.

73 Wild R, Pettit T, Burns A: Cholinesterase inhibitors for dementia with Lewy bodies. Cochrane Database Syst Rev 2003;CD003672.

74 Levine DA, Langa KM: Vascular cognitive impairment: disease mechanisms and therapeutic implications. Neurotherapeutics 2011;8:361-373.

75 Malouf R, Birks J: Donepezil for vascular cognitive impairment. Cochrane Database Syst Rev 2004;CD004395. 